\title{
Health of an ex situ population of raptors (Falconiformes and Strigiformes) in Mexico: diagnosis of internal parasites
}

Tiziano Santos ${ }^{1,2}$, Jaqueline B. de Oliveira ${ }^{1,3 /+}$, Christopher Vaughan ${ }^{1,4,5}$ \& Heber Santiago ${ }^{6}$

1. Instituto Internacional de Manejo y Conservación de Vida Sivestre (ICOMVIS), Universidad Nacional Autónoma, Apdo. 1350-3000, Heredia, Costa Rica.

2. Laboratorio de Parasitología Veterinaria, Facultad de Estudios Superiores Cuautitlan Campo IV, Universidad Nacional Autonoma de México, Km 2.5 carretera a Cuautitlan-Eoloyucan, San Sebastian Xhala, Cuautitlan Izcalli, Estado de Mexico, México, CP. 54714; tizizoo@yahoo.com

3. Cátedra de Parasitologia, Departamento de Biologia, Universidade Federal Rural de Pernambuco (UFRPE), Rua Dom Manoel de Medeiros SN, Recife, CEP 52171-900, Pernambuco, Brasil; bianque01@yahoo.com.br

4. Department of Forest and Wildlife Ecology, University of Wisconsin-Madison, Madison, WI 53706 USA; cvaughan@wisc.edu

5. Associated Colleges of the Midwest, Apartado 2562-2050, San Pedro, Costa Rica; cvaughan@acm.or.cr

6. Centro de Investigación y Conservación de Vida Silvestre (CIVS), Circuito Emiliano Zapata Norte, esq. con Circuito Emiliano Zapata Sur, s/n, col. El Pino, Los Reyes La Paz, Estado de México, México, CP. 56507; hrslopez@ yahoo.com

Received 19-V-2010. C Corrected 03-I-2011. Accepted 01-II-2011.

\begin{abstract}
Successful programs for ex situ and in situ conservation and management of raptors require detailed knowledge about their pathogens. The purpose of this study was to identify the internal parasites of some captive raptors in Mexico, as well as to verify their impact in the health status of infected birds. Birds of prey were confiscated and kept in captivity at the Centro de Investigación y Conservación de Vida Silvestre (CIVS) in Los Reyes La Paz, Mexico State. For this, fecal and blood samples from 74 birds of prey (66 Falconiformes and eight Strigiformes) of 15 species, juveniles and adults from both sexes ( 39 males and 35 female), were examined for the presence of gastrointestinal and blood parasites. Besides, the oropharyngeal cavity was macroscopically examined for the presence of lesions compatible with trichomoniasis. Among our results we found that lesions compatible with Trichomonas gallinae infection were detected only in two Red-tailed hawks (Buteo jamaicensis) (2.7\%); nevertheless, infected birds were in good physical condition. Overall, gastrointestinal parasites were found in $10(13.5 \%)$ raptors: nine falconiforms $(13.6 \%)$ and one strigiform $(12.5 \%)$, which mainly presented a single type of gastrointestinal parasite (90\%). Eimeria spp. was detected in Harris's hawk (Parabuteo unicinctus), Swainson's hawk (Buteo swainsoni), Red-tailed hawk (B. jamaicensis) and Great horned owl (Bubo virginianus); whereas trematodes eggs were found in Peregrine falcon (Falco peregrinus) and Swainson's hawk (B. swainsoni). Furthermore, eggs of Capillaria spp. were found in one Swainson's hawk (B. swainsoni), which was also infected by trematodes. Hemoprotozoarian were detected in five (6.7\%) falconiforms: Haemoproteus spp. in American kestrel (F. sparverius) and Leucocytozoon spp. in Red-tailed hawk (B. jamaicencis). Despite this, no clinical signs referable to gastrointestinal or blood parasite infection were observed in any birds. All parasites identified were recorded for the first time in raptors from Mexico. Furthermore, this represents the first report for T. gallinae, trematodes, Haemoproteus spp. and Leucocytozoon spp. in raptors from Latin America. Diagnosis and control of parasitic infections should be a part of the routine in health care evaluations for ex situ raptor populations. Finally, this information is also valuable for in situ conservation actions on these birds. Rev. Biol. Trop. 59 (3): 1265-1274. Epub 2011 September 01.
\end{abstract}

Key words: raptors, gastrointestinal parasites, hemoparasites, conservation, captivity.

In the last decades, a substantial volume of medical information has become available as a result of the increased interest in raptors
(Fix \& Barrows 1990, Wendell et al. 2002, Naldo \& Samour 2004). According to several studies, the most common causes of morbidity 
in these birds are infectious and parasitic diseases, traumatic injuries, toxicosis, and metabolic or nutritional diseases (Fix \& Barrows 1990, Deem et al. 1998, Wendell et al. 2002, Naldo \& Samour 2004). Infectious diseases caused by bacterial, viral, fungal, and/or parasitic origin are common in wild and captive birds of prey (Deem 1999, Jones 2006). Though parasites are the most frequent pathogens in raptors, the gastrointestinal and respiratory tracts are most commonly affected by nematodes, trematodes, cestodes, acanthocephalans and protozoans (Baker et al. 1996, Aguilar 2001, Ferrer et al. 2004a, Ferrer et al. 2004b, Leppert et al. 2008, Silva et al. 2009). Overt clinical signs of parasitism are not common, subclinical parasitism may become evident during stress conditions, and heavy infections by gastrointestinal parasites may cause diarrhea, anorexia, emaciation, listlessness, and death (Baker et al. 1996, Morishita 1997, Freitas et al. 2002, Jones 2006).

Much debate exists regarding the pathogenicity of hemoparasites in raptors. Most researchers agree that Plasmodium spp. is of clinical significance and may result in signs of depression, weight loss, labored respiratory effort, anemia, and decreased appetite (Deem 1999, Jones 2006). This way, the diagnosis and control of parasitic infections should be part of the routine in protocols with captive raptors (Morishita 1997, Deem 1999). Furthermore, the review of morbidity and mortality causes in captive raptors, may provide insight about the health status and conservation of wild populations (Wendell et al. 2002, Deem et al. 2008). Besides, successful work in the field of conservation and management (ex situ and in situ) of raptors requires detailed knowledge about their pathogens (Baker et al. 1996, Morishita 1997, Morishita et al. 1998, Deem et al. 2008).

At present, several Mexican raptors are included in Appendices I and II of the Convention on International Trade in Endangered Species of Wild Fauna and Flora (CITES) (Peterson \& Chalif 1989). Some endemic species of diurnal (Falconiformes) and nocturnal (Strigiformes) raptors are kept in captivity in
Mexico, but studies about the parasite fauna in these birds are scarce (Santos-Morin 2010). Aiming to generate new information, the purpose of this search was to identify the internal parasites of some captive raptors in Mexico, as well as to determine their impact on their health status.

\section{MATERIALS AND METHODS}

Study population: Between January and December 2008, 74 raptors (66 Falconiformes and eight Strigiformes) of 15 species (Table 1), juveniles and adults from both sexes (39 males and 35 female), were evaluated for the presence of Trichomonas gallinae, gastrointestinal and blood parasites. The birds were confiscated by the Secretaria del Medio Ambiente y Recursos Naturales (SEMARNAT) because their breeders were not licensed to keep wildlife nor avian species. Birds were kept at the Centro de Investigación y Conservación de Vida Silvestre (CIVS) in Los Reyes La Paz (20'22'N, $\left.98^{\circ} 59^{\prime} \mathrm{W}\right)$, Mexico State. The CIVS is located at an altitude of 2250 masl. The climate is hot and dry with a mean temperature of $16.4^{\circ} \mathrm{C}$ and a relative humidity of $70 \%$. Annual precipitation is $800-900 \mathrm{~mm}$.

Apart from the absence of licenses, other causes for admission at the CIVS included: acute traumatic injuries, electrocution , infectious diseases, orphaned young, metabolic and/ or nutritional diseases. Since all the birds were originally found in several counties in Mexi$\mathrm{co}$, the information regarding their origins was unavailable.

All CIVS birds were long-term captive raptors. According to Morishita et al. (2001), free-living raptors are defined as birds that have been in captivity less than 24 hours, and were solely admitted because of acute traumatic injuries, thus increasing the probability of otherwise healthy subjects, free from seasonal dietary stresses, and with normal parasite burdens.

The 74 raptors lived in 12 enclosures, definided as following: A $(n=8), B(n=11), C$ $(n=4), D(n=8), E(n=3), F(n=6), G(n=7), H$ 
TABLE 1

Gastrointestinal and blood parasites of raptors kept in captivity at the Centro de Investigación y Conservación de Vida Silvestre (CIVS) of Mexico, January to December 2008

\begin{tabular}{|c|c|c|c|c|}
\hline Orden & Species & Examined & Infected & Internal parasites \\
\hline \multirow[t]{10}{*}{ Falconiformes } & Falco sparverius (American kestrel) & 8 & 4 & Haemoproteus spp. \\
\hline & F. peregrinus (Peregrine falcon) & 3 & 2 & Trematodes \\
\hline & Caracara cheriway (Caracara) & 6 & - & \\
\hline & Buteo swainsoni (Swainson's hawk) & 3 & 3 & $\begin{array}{l}\text { Eimeria } \text { spp., Trematodes, } \\
\text { Capillaria } \text { spp. }\end{array}$ \\
\hline & B. nitidus (Grey hawk) & 5 & - & \\
\hline & B. jamaicensis (Red-tailed hawk) & 18 & 4 & $\begin{array}{l}\text { Trichomonas gallinae, } \\
\text { Eimeria spp., Leucocytozoon } \\
\text { spp. }\end{array}$ \\
\hline & Buteo albicaudatus (White-tailed hawk) & 1 & - & \\
\hline & Parabuteo unicinctus (Harris's hawk) & 20 & 3 & Eimeria spp. \\
\hline & Buteogallus antrhacinus (Common black hawk) & 1 & - & \\
\hline & Accipiter striatus (Sharp-shinned hawk) & 1 & - & \\
\hline \multirow[t]{5}{*}{ Strigiformes } & Bubo virginianus (Great horned owl) & 4 & 1 & Eimeria spp. \\
\hline & Strix virgata (Mottled owl) & 1 & & \\
\hline & Athene cunicularia (Burrowing owl) & 1 & & \\
\hline & Megascops asio (Eastern screech owl) & 1 & & \\
\hline & Tyto alba (Barn owl) & 1 & & \\
\hline
\end{tabular}

$(\mathrm{n}=1), \mathrm{I}(\mathrm{n}=10), \mathrm{J}(\mathrm{n}=6), \mathrm{K}(\mathrm{n}=3)$ and $\mathrm{L}(\mathrm{n}=7)$. Enclosures allow limited flight and included weather protected sites and resting perches. Cages were encompassed by wire or plastic screen net siding, and birds were exposed to ambient weather conditions. Enclosures were raked two or three times/week.

Birds were fed three days/week with thawed chicks, mice or rats and given free access to water.

The health status of birds was evaluated and classified by their weight as follows: thin, good condition and obese (Greenacre 2003, Haire 2003).

For the parasite control, birds were dewormed (with fenbendazole or ivermectin) upon arrival and twice a year. This deworming was performed only in the presence of clinical signs. Periodically, infested birds were treated with organophosphorate dusting.

Additionally, birds were provided with veterinary medical attention and/or flight rehabilitation as needed.
Infection by $T$. gallinae: To study the clinical infection by $T$. gallinae, the oropharynx of birds were examined macroscopically, for presence of white and caseous lesions, or stomatitis as indicator for trichomonosis (Cooper 1978, Real et al. 2000, Krone et al. 2005). Unfortunately, confirmatory oropharyngeal swabs could not be performed.

Gastrointestinal parasites: Fecal sample collection was performed twice (with an interval of 15 days), two months after the last deworming. Seventy-four fresh fecal samples were collected from newspapers or plastic covers on the cage floor (for 12 hours) (Clyde \& Patton 2000, Silva et al. 2009). Samples were transported in plastic bags on ice, and kept at $4^{\circ} \mathrm{C}$, for processing generally within one week (Freitas et al. 2002).

Fecal samples were analyzed for Sheather's flotation (hypersaturated sugar solution, density $1.3 \mathrm{~g}$ ) and sedimentation techniques (Baker et al. 1996, Freitas et al. 2002). When 
unsporulated coccidial oocysts were found during flotation examination, an aliquot was placed in a $2 \%$ potassium dicromate solution at $28^{\circ} \mathrm{C}$ for at least 1 week, and the flotation procedure was then repeated (Freitas et al. 2002). Cysts, oocysts and eggs were identified by their morphology and size (Baker et al. 1996, Foreyt 2001, Freitas et al. 2002). Whenever possible, the parasites were identified to genus.

Blood parasites: A total of 74 blood samples were obtained by venepuncture of the medial metatarsal vein; thin blood smears were made and air dried (Muñoz et al. 1999, Leppert et al. 2008). At the laboratory, they were fixed in absolute methanol and stained with Giemsa's solution. Then, slides were examined with a high-power microscope under immersion oil (100X) for a total observation of 120 to 130 microscope fields for each smear (Muñoz et al. 1999). Because speciation of Haemoproteus and Leucocytozoon is difficult based on morphology alone (Ziman et al. 2004), only the genus was recorded.

\section{RESULTS}

In general, $52.7 \%$ of the raptors presented good physical condition. Thin and obese birds $(31.1 \%$ and $16.2 \%$, respectively) were also observed.

Infection by $\boldsymbol{T}$. gallinae: The presence of caseous lesions (compatibles with the infection by $T$. gallinae) was observed in the oropharinx of two $(2.7 \%)$ Buteo jamaicensis (Table 1). Nevertheless, the birds were in good physical condition.

Gastrointestinal parasites: Overall, the gastrointestinal parasites were found in 10 (13.5\%) of 74 birds. Of the 66 falconiforms examined, nine $(13.6 \%)$ were infected. In the case of strigiform infection, it was present only in one $(12.5 \%)$ of the eight examined birds. The majority of birds (90\%) were infected with a single type of parasite.
The following parasites were identified from the analyzed samples: oocysts of Eimeria spp., trematodes and Capillaria spp. eggs. Eimeria spp. was found in Parabuteo unicinctus $(\mathrm{n}=3), B$. swainsoni $(\mathrm{n}=1), B$. jamaicensis $(\mathrm{n}=1)$ and Bubo virginianus $(\mathrm{n}=1)$; whereas trematodes eggs were found in Falco peregrinus $(\mathrm{n}=2)$ and B. swainsoni $(\mathrm{n}=2)$. Eggs of Capillaria spp. were found in one B. swainsoni, which was also infected by trematodes (Table 1). Furthermore, no clinical signs, referable to parasite infection, were observed in any birds.

Blood parasites: Hemoparasites (Apicomplexa, Haemosporida) were found in five (6.7\%) birds. Haemoproteus spp. was found in four F. sparverius, and Leucocytozoon spp. in one B. jamaicencis (Table 1).

\section{DISCUSSION}

Many parasitic pathogens of birds of prey are opportunistic and can be easily managed or averted with proper preventive measures related to captive management, husbandry and diet, and veterinary care (Morishita 1997, Morishita et al. 1998, Deem 1999, Freitas et al. 2002, Joseph 2006, Willette et al. 2009). The knowledge of parasites commonly found in raptors contributes and help ensure prompt, appropriate and judicious control measures (Baker et al. 1996, Joseph 2006, Silva et al. 2009, Willette et al. 2009). Despite this, there are limited studies about the parasites of raptors in Latin America.

Trichomoniasis is the most important parasitic disease of raptors, and has been reported worldwide in these birds (Boal et al. 1998, Deem 1999, Real et al. 2000). According to Fowler (2001), the trichomoniasis is more frequent in strigiforms than in falconiforms. However, in this study, lesions compatible with trichomoniasis were found solely in two Redtailed hawks (B. jamaicensis) newly-arrived to the CIVS. It is likely that the birds were infected upon arrival at CIVS, since in this Center birds were not fed with pigeons or other columbiforms, the main primary hosts of $T$. 
gallinae, a sarcomastigophoran protozoa (Real et al. 2000, Krone et al. 2005).

Most of the strains of $T$. gallinae are found in the upper digestive tract of their hosts, and are considered to be non-pathogenic; however, others are highly virulent and are responsible for proliferative lesions on the tongue and oropharyngeal surfaces (Cooper \& Petty 1988, Samour et al. 1995, Real et al. 2000, Aguilar 2001, Sansano-Maestre et al. 2009). Studies revealed marked differences in pathogenicity and virulence among different strains of $T$. gallinae from pigeons and birds of prey (Sansano-Maestre et al. 2009). The bird may have difficulty swallowing and, in severe infections, may be emaciated because of its inability to eat (Boal et al. 1998, Deem 1999). Nevertheless, affected birds may have good physical condition, and after the appropriate treatment, lesions disappear (Real et al. 2000, Jones 2006). Capillariasis, candidiasis, hypovitaminosis A and bacterial abscesses may also cause oral lesions, similar to those of trichomonad infections, especially in the early stages (Deem 1999, Krone et al. 2005, Jones 2006). Capillariasis is different from trichomoniasis and is often more extensive, with lesions in mouth, oropharynx, esophagus, crop, small intestine and cecum (Deem 1999). Candidiasis is often secondary to an underlying inmunocompromising condition or prolonged antibiotic therapy (Deem 1999, Jones 2006). In this study, despite of clinic diagnosis, lesions disappeared after the treatment with metronidazole. For the first time, lesions compatible with trichomoniasis are recorded in raptors for Latin America. Further research is needed to investigate the prevalence of $T$. gallinae infections in birds of prey of the region.

Several gastrointestinal parasites frequently reported in raptors worldwide (Hoberg et al. 1989, Ferrer et al. 2004a, Ferrer et al. 2004b) were not identified in this study. Failure to identify some parasites may be due to differences in the geographic distribution of the hosts and/or parasites, the feeding habits of host species, and the material origin (Baker et al. 1996). Most studies used samples from necropsies, whereas this study was based in coprologic analysis. With necropsy material, the helminths are most prevalent in wild and captive raptors (Hoberg et al. 1989, Ferrer et al. 2004a, Ferrer et al. 2004b), whereas protozoa are most prevalent in coprologic surveys (Baker et al. 1996, Silva et al. 2009). Gastrointestinal parasites found in this study are reported in many species of captive and wild raptors worldwide (Greenwood et al. 1984, Baker et al. 1996, Freitas et al. 2002, Silva et al. 2009); however, Eimeria spp., trematodes and Capillaria spp. were recorded for the first time in birds of prey from Mexico. Similar to the report of Baker et al. (1996) in raptors from United States, the birds had single infections; whereas the mixed infections were most prevalent in captive strigiforms from Brazil (Silva et al. 2009). Coccidia and trematodes were also diagnosed in a coprologic survey of wild and captive falconiforms and strigiformes from United States (Baker et al. 1996); whereas Coccidia and Strongylida were found in fecal samples from captive strigiforms from Brazil (Silva et al. 2009).

Eimeria spp. is one of the most reported Coccidia in birds of prey, perhaps because it is a directetly transmitted parasite; furthermore, oocysts are very resistant to adverse environmental conditions (Baker et al. 1996, Freitas et al. 2002). In this survey, Eimeria spp. was found in Swainson's hawk (B. swainsoni), Redtailed hawk (B. jamaicensis), Harris's hawk (P. unicinctus) and Great Horned owl (Bubo virginianus). The Coccidia Caryospora uptoni has been recorded in B. jamaicensis; while Eimeria sp., Caryospora sp. and Frenkelia-like were found in B. jamaicensis, and Eimeria sp. in B. virginianus (Lindsay \& Blagburn 1986, Baker et al. 1996). Cryptosporidium spp. was detected by Ziehl-Neelsen technique in captive Bubo virginianus and Tyto alba (Barn owl) from Brazil (Silva et al. 2009).

Trematodes eggs were found only in falconiformes, such as the Peregrine falcon $(F$. peregrinus) and Swainson's hawk (B. swainsoni). Baker et al. (1996) detected trematodes eggs in falconiformes and strigiformes from 
United States. Common trematode genera from raptors include: Strigea, Parastrigea, Neodiplostomum, Brachylaima and Brachylecithum (Greenwood et al. 1984, Ferrer et al. 2004a, Ferrer et al. 2004b, Sanmartín et al. 2004). It is not possible to identify trematode genera based in the eggs morphology (Greenwood et al. 1984). Strigea falconis and Neodiplostomum attenuatum are frequently reported in $F$. peregrinus, and are transmitted by small vertebrates that are frequent prey items for this raptor (Greenwood et al. 1984, Sanmartín et al. 2004). This is the first finding of trematodes eggs in fecal samples in raptors from Latin America.

Infections by Capillaria spp. are recorded in raptors worldwide (Hoberg et al. 1989, Deem 1999, Ferrer et al 2004a, Ferrer et al. 2004b, Sanmartín et al. 2004). In the present survey, this nematode was found only in the falconiform Swainson's hawk (B. swainsoni), whereas Baker et al. (1996) detected the presence of Capillaria spp. eggs in falconiforms and strigiforms. According to Fowler (2001), Capillaria spp. is prevalent in wild (78\%) than in captive $(7 \%)$ strigiforms from North and South America.

In captivity, the birds live in persistent contamined cages, supporting reinfections despite periodic dewormings (Freitas et al. 2002). Deworming drugs (fenbendazole or ivermectin) used in the CIVS are not effective against some gastrointestinal parasites detected in this study (Eimeria spp. and trematodes), which underlie the importance of coprologic examination as a parameter for deworming (Freitas et al. 2002). Moreover, a report of suspected fenbendazole toxicity with bone-marrow suppression in several species of birds, should alert practitioners to adecuatelly monitor raptors receiving this drug (Deem 1999).

Haemoproteus spp., Leucocytozoon spp., Plasmodium spp. and Trypanosoma avium are the hematozoa recorded in birds of prey worldwide (Deem 1999, Muñoz et al. 1999, Remple 2004, Ishak et al. 2008, Krone et al. 2008, Leppert et al. 2008). Nevertheless, this is a first record of Haemoproteus spp. and
Leucocytozoon spp. in captive American kestrels ( $F$. sparverius) and Red-tailed hawk (B. jamaicensis), respectively, in Latin America. Haemoproteus spp. and Leucocytozoon spp., detected only in falconiforms, were also reported by researchers in United States, Canada, Panama and Italy (Maloney et al. 1984, Sacchi \& Prigioni 1984, Ziman et al. 2004). On the contrary, Leucocytozoon sp. was the most prevalent blood parasite from falconiforms from a recovery center in Spain (Muñoz et al. 1999). $H$. tinnunculus and H. elani have been recorded in kestrels worldwide, whereas L. toddi is the only species reported to occur in falconiforms (Maloney et al. 1984, Olsen \& Gaunt 1985, Krone et al. 2008).

B. jamaicensis (Red-tailed hawk) and $B$. swainsoni (Swainson's hawk) were the raptors that presented greater diversity of internal parasites, so these should receive special attention in captive bird conditions.

Evaluated raptors presented good physical condition and no clinical signs referable to gastrointestinal or blood parasite infections were observed in any birds, probably due to the mild nature of the infections in captive animals (Baker et al. 1996, Freitas et al. 2002, Silva et al. 2009). Raptors are infrequently affected clinically by overt parasitism, but subclinical parasitism may become evident during stress conditions, which is frequent in captivity and heavy infections by gastrointestinal parasites that may cause diarrhea, anorexia, emaciation, listlessness, and death (Baker et al. 1996, Morishita 1997, Freitas et al. 2002). Much debate exists regarding hemoparasites pathogenicity in raptors, which have been associated to decreased body condition of birds during breeding season in many regions (Deem 1999, Leppert et al. 2008). Latent hemoprotozoal infection may be activated in critically ill raptors, yet may not harm the host (Maloney et al. 1984). According to Olsen \& Gaunt (1985) weakened or injured raptors with hemoprotozoal infection had longer rehabilitation time and a higher mortality rate than those without infection. 
Captive breeding programs are aimed to maintain genetically viable, healthy populations for subsequent release into the wild (Daszak et al. 2000, Daszak et al. 2001). The CIVS has a release program of some rehabilited raptors, which may occur in protected areas of Mexico. According to Daszak et al. (2000, 2001), the potential transfer of pathogens into previously unexposed wild populations in often sensitive protected areas, represents a serious challenge to conservation efforts. This can impinge on release programs even when no apparent disease (like subclinical parasitism) is observed. Diagnosis of parasites in raptors in the CIVS is very important to avoid the accidental introduction of a pathogenic (or potencially pathogenic) parasite to a new (or native) host species or population in wildlife. The process of host-parasite cointroduction, termed "pathogen pollution" (Cunningham 1996, Daszak et al. 2000), may have a heightened ecological impact by conferring competitive advantage to the invading host, a phenomenon known as "apparent competition" or "parasite-mediated competition (Cunningham et al. 2003). In United States, three subspecies of Spotted owl (Strix occidentalis caurina, S. o. occidentalis and S. o. lucida) are threatened by habitat loss and the range expansion of the Barred owl (S. varia) (which is also a source of novel pathogens, such as blood parasites), potentially harmful for threatened Spotted owls (Ishak et al. 2008). Pathogen pollution may have significant implications for animal welfare, endangering the conservation status of wildlife due to biodiversity loss (Daszak et al. 2000, Cunningham et al. 2003).

According to Daszak et al. (2000), the conservation community has drawn up guidelines to prevent the release of animals carrying pathogens. Unfortunately, the main recommendations are currently underused: of almost 700 terrestrial vertebrate translocations (within conservation programs) between 1973 and 1986 in the United States, Australia, Canada and New Zealand, 24\% occurred without any disease screening and fewer than $25 \%$ involved investigations into causes of death of the translocated animals (Daszak et al. 2000).

For all these reasons, in conservation centers such as the CIVS, a health assessment that includes physical examination, fecal and blood parasite evaluation, hematology and plasma biochemical analysis should be performed routinely (trimestrial or half-yearly) in incoming and long-term captive raptors. Much debate exists regarding endoparasites treatment in captive animals and there is no consensus, since for some authors the loss of host-specific parasites from species in captive breeding programs is also a substantial threat to biodiversity conservation (Daszak et al. 2000, Cunningham et al. 2003). In addition to ethical obligations to preserve parasite assemblages along with their more favored hosts, the maintenance of established host-parasite relations may be important for the overall well-being of the host species, both at an individual (maintenance of immunity) and at a population level (maintenance of genetic diversity) (Daszak et al. 2000, Cunningham et al. 2003). For some researchers, some raptors parasites are opportunistic, thereby captive infected birds should be treated (Morishita 1997, Deem 1999, Morishita et al. 2001, Joseph 2006, Willette et al. 2009).

Findings from this study have been used to make recommendations to the Secretaria del Medio Ambiente y Recursos Naturales (SEMARNAT) for improvements in husbandry and veterinary care of this ex situ population. Furthermore, due to the fact that the CIVS is also a rehabilitation center of wild birds of prey, the knowledge of the causes of morbidity and mortality of incoming and long-term captive raptors, may provide insight into the health status and conservation of wild populations which should be studied in the future.

\section{ACKNOWLEDGMENTS}

We acknowledge the staff of the Centro de Investigación y Conservación de Vida Silvestre (CIVS). Tiziano Santos was supported in part by grants from the U.S. Fish and Wildlife Service. 


\section{RESUMEN}

El éxito de los programas de conservación de rapaces (ex situ and in situ) requiere de un conocimiento detallado de sus patógenos. El objetivo de este estudio fue identificar los parásitos internos de rapaces en cautiverio en México, así como verificar su repercusión en el estado de salud de las aves. Las mismas fueron estudiadas, decomisadas y mantenidas en el Centro de Investigación y Conservación de Vida Silvestre (CIVS) en Los Reyes La Paz, estado de México. Las muestras de heces y sangre de 74 rapaces (66 Falconiformes y ocho Strigiformes) de 15 especies, juveniles y adultos de ambos sexos (39 machos y 35 hembras), fueron examinadas para analizar la presencia de parásitos gastrointestinales y sanguíneos. Asimismo, la cavidad orofaríngea fue evaluada macroscópicamente para verificar la presencia de lesiones compatibles con trichomoniasis. Lesiones compatibles con la infección por Trichomonas gallinae fueron detectadas en dos $(2.7 \%)$ Buteo jamaicensis; no obstante, las aves infectadas estaban en buena condición física. En general, los parásitos gastrointestinales fueron encontrados en $10(13.5 \%)$ rapaces: nueve (13.6\%) Falconiformes y uno (12.5\%) Strigiformes; los cuales presentaron un único tipo de parásito gastrointestinal (90\%). Eimeria spp. fue detectada en Parabuteo unicinctus, $B$. swainsoni, B. jamaicensis y Bubo virginianus; mientras que los tremátodos lo fueron en Falco peregrinus y B. swainsoni. Capillaria spp. fue diagnosticada únicamente en $B$. swainsoni. Los hemoparásitos fueron encontrados en $6.7 \%$ de los Falconiformes: Haemoproteus spp. en F. sparverius y Leucocytozoon spp. en B. jamaicencis. No fueron observados signos clínicos relacionados con la infección por los parásitos internos. Todos los parásitos identificados son reportados por primera vez en rapaces de México. De tal manera que, T. gallinae, y los trematódos: Haemoproteus spp. y Leucocytozoon spp. son reportados en rapaces en Latinoamérica por primera vez. El diagnóstico y control de las infecciones parasitarias deberían ser parte de la rutina de los cuidados de salud de poblaciones de rapaces ex situ. Además, la información obtenida es de gran valor para la conservación in situ de estas aves.

Palabras clave: rapaces, parásitos gastrointestinales, hemoparásitos, conservación, cautiverio.

\section{REFERENCES}

Aguilar, R.F. 2001. Raptor Medicine and Surgery, p. 118124. In M.E. Fowler \& Z.S. Cubas (eds). Biology, Medicine and Surgery of South American Wild Animals. Iowa State University, Iowa, USA.

Baker, D.G., T.Y. Morishita, J.L. Bartlett \& D.L. Brooks. 1996. Coprologic survey of internal parasites of northern California raptors. J. Zoo Wild. Med. 27: $358-363$.
Boal, C.W., R.W. Mannan \& K.S. Hudelson. 1998. Trichomoniasis in Cooper's hawks from Arizona. J. Wildl. Dis. 34: 590-593.

Clyde, V. \& S. Patton. 2000. Parasitism of caged birds, p. 424-448. In G. Olsen \& S. Orosz (eds). Manual of avian medicine. Mosby, New York, USA.

Cooper, J.E. 1978. Parasites, p. 82-96. In J.E. Cooper (ed.). Veterinary aspects of captive birds of prey.The Standfast, Cherington, United Kingdom.

Cooper, J.E. \& D.J. Petty. 1988. Trichomoniasis in freeliving goshawks (Accipiter gentilis gentilis) from Great Britain. J. Wildl. Dis. 24: 80-87.

Cunningham, A.A. 1996. Disease risks of wildlife translocations. Conserv. Biol. 10: 349-353.

Cunningham, A.A., P. Daszak \& J.P. Rodríguez. 2003. Pathogen pollution: defining a parasitological threat to biodiversity conservation. J. Parasitol. 89 (Suppl.): S78-S83.

Daszak, P., A.A. Cunningham \& A.D. Hyatt. 2000. Emerging infectious diseases o wildlife - threats to biodiversity and human health. Science 87: 443-449.

Daszak, P., A.A. Cunningham \& A.D. Hyatt. 2001. Anthropogenic environmental change and the emergence of infectious diseases in wildlife. Acta Trop. 78: 103-116.

Deem, S.L. 1999. Infectious and parasitic diseases of raptors. Comp. Cont. Vet. Educ. Pract. Vet. 21: 329-338.

Deem, S.L., S.P. Terrel \& D.J. Forrester. 1998. A retrospective study of morbidity and mortality of raptors in Florida: 1988-1994. J. Zoo Wildl. Med. 29: 160-164.

Deem, S.L., E. Ladwing, C. Cray, W.B. Karesh \& G. Amato. 2008. Health assessment of the ex situ population of St Vicent parrots (Amazona guildingii) in St Vicent and the Grenadines. J. Avian Med. Surg. 22: 114-122.

Ferrer, D., R. Molina, C. Adelantado \& J.M. Kinsella. 2004a. Helminths isolated from the digestive tract of diurnal raptors in Catalonia, Spain. Vet. Rec. 3: 17-20.

Ferrer, D., R. Molina, C. Adelantado \& J.M. Kinsella. 2004b. Parasitic helminths in the digestive tract of six species of owls (Strigiformes) in Spain. Vet. J. 167: 181-185.

Fix, A.S. \& S.Z. Barrows. 1990. Raptors rehabilitated in Iowa during 1986 and 1987: a retrospective study. J. Wildl. Dis. 26: 18-21. 
Foreyt, W. 2001. Veterinary Parasitology Reference Manual. Fifth edition. Blackwell, United Kingdom.

Fowler, M.E. 2001. Order Strigiformes (Owls), p. 125-132. In M.E. Fowler \& Z. Cubas (eds.). Biology, Medicine and Surgery of South American Wild Animals. Iowa State University, Iowa, USA.

Freitas, M.F.L., J.B. Oliveira, M.D.B. Cavalcanti, A.S. Leite, V.S. Magalhães, R.A. Oliveira \& A. Evencio-Sobrinho. 2002. Parásitos gastrointestinales aves silvestres en cautiverio en el estado de Pernambuco, Brasil. Parasitol. Día 57: 50-54.

Greenacre, C. 2003. The avian patient. p. 5-29. In B. Ballard \& R. Cheek (eds.). Exotic animal medicine for the veterinary technician. Blackwell, USA.

Greenwood, A.G., C.W. Furley \& J.E. Cooper. 1984. Intestinal trematodiasis in falcons (order Falconiformes). Vet. Rec. 12: 477-478.

Haire, M. 2003. The role of the veterinary technician in wildlife rehabilitation, p. 237-306. In B. Ballard \& R. Cheek (eds.). Exotic Animal Medicine for the Veterinary Technician. Blackwell, USA.

Hoberg, E.P., G.S. Miller, E. Wallner-Pendleton \& O.R. Hedstrom. 1989. Helminth parasites of northern spotted owls (Strix occidentalis caurina) from Oregon. J. Wildl. Dis. 25: 246-251.

Ishak, H.D., J.P. Dumbacher, N.L. Anderson, J.J. Keane, G. Valkiünas, S.M. Haig, L.A. Tell \& R.N. Sehgal. 2008. Blood parasites in owls with conservation implications for the spotted owl (Strix occidentalis). Plos One 28: 2304.

Jones, M.P. 2006. Selected infectious diseases of birds of prey. J. Exot. Pet Med. 15: 5-17.

Joseph, V. 2006. Raptor medicine: an approach to wild, falconry, and educational birds of prey. Vet. Clin. North Am. Exot. Anim. Pract. 9: 321-345.

Krone, O., R. Altenkamp \& N. Kenntner. 2005. Prevalence of Trichomonas gallinae in northern goshawks from the Berlin area of northeastern Germany. J. Wildl. Dis. 41: 304-309.

Krone, O., J. Waldenström, G. Valkiūnas, O. Lessow, K. Müller, T.A. Iezhova, J. Fickel \& S. Bensch. 2008. Haemosporidian blood parasites in European birds of prey and owls. J. Parasitol. 94: 709-715.

Leppert, L.L., A.M. Dufty Jr., S. Stock, M.D. Oleyar \& G.S. Kaltenecker. 2008. Survey of blood parasites in two forest owls, northern saw-whet owls and flammulated owls, of western north America. J. Wild. Dis. 44: 475-479.

Lindsay, D.S. \& B.L. Blagburn. 1986. Caryospora uptoni n. sp. (Apicomplexa: Eimeriidae) from red-tailed hawks (Buteo jamaicensis borealis). J. Parasitol. 72: 762-765.

Maloney, P.J., G.F. Bennett, D.M. Bird \& D.J. Lewis. 1984. Haemoproteus tinnunculus in the american kestrel (Falco sparverius). J. Wildl. Dis. 20: 57-58.

Morishita, T.Y. 1997. Parasites of raptors and developing a parasite monitoring and prevention program. Wildl. Rehab. 15: 119-133.

Morishita, T.Y., A.T. Fullerton, L.J. Lowesnstine, I.A. Gardner \& D.L. Brooks. 1998. Morbidity and mortality in free-living raptorial birds of northern California: a retrospective study. J. Avian Med. Surg. 12: 78-81.

Morishita, T.Y., J.W. Mertins, D.G. Baker, C.M. Monahan \& D.L. Brooks. 2001. Occurrence and species of lice on free-living and captive raptors in California $\mathrm{J}$. Avian Med. Surg. 15: 288-292.

Muñoz, E., D. Ferrer, R. Molina \& R.D. Adlard. 1999. Prevalence of haematozoa in birds of prey in Catalonia, north-east Spain. Vet. Rec. 144: 632-636.

Naldo, J.L. \& J.H. Samour. 2004. Causes of morbidity and mortality in falcons in Saudi Arabia. J. Avian Med. Surg. 18: 229-241.

Olsen, G.H. \& S.D. Gaunt. 1985. Effect of hemoprotozoal infections on rehabilitation of wild raptors. JAVMA 187: 1204-1205.

Peterson, R.T. \& E.L. Chalif. 1989. Aves de México. Diana, D.F, México.

Real, J., S. Mañosa \& E. Muñoz. 2000. Trichomoniasis in a Bonelli's eagle population in Spain. J. Wildl. Dis. 36: 64-70.

Remple, D. 2004. Intracellular hematozoa of raptors: a review and update. J. Avian Med. Surg. 18: 75-88.

Sacchi, L. \& C. Prigioni. 1984. Occurrence of Leucocytozoon and Haemoproteus (Apicomplexa, Haemosporina) in Falconiformes and Strigiformes of Italy. Ann. Parasitol. Hum. Comp. 59: 219-226.

Samour, J.H., T.A. Bailey \& J.E. Cooper. 1995. Trichomoniasis in birds of prey (Order Falconiformes) in Bahrain. Vet. Rec. 136: 358-362. 
Sanmartín, M.L., F. Álvarez, G. Barreiro \& J. Leiro. 2004. Helminth fauna of falconiform and strigiform birds of prey in Galicia, Northwest Spain. Parasitol. Res. 92: $255-263$.

Sansano-Maestre, J., M.M. Garijo-Toledo, M.T. GómezMuñoz. 2009. Prevalence and genotyping of Trichomonas gallinae in pigeons and birds of prey. Avian Pathol. 38: 201-207.

Santos-Morin, T. 2010. Diagnóstico y control de parásitos: repercusión en la conservación ex situ de aves rapaces en México. Tesis de Maestría, Universidad Nacional Autónoma, Heredia, Costa Rica.

Silva, A.S., R.A. Zanette, V.M. Lara, L.T. Gressler, A.B. Carregaro, J.M. Santurio \& S.G. Monteiro. 2009. Gastrointestinal parasites of owls (Strigiformes) kept in captivity in the Southern region of Brazil. Parasitol. Res. 104: 485-487.

Wendell, M.D., J.M. Sleeman \& G. Kratz. 2002. Retrospective study of morbidity and mortality of raptors admitted to Colorado State University Veterinary Teaching Hospital during 1995 to 1998 . J. Wild. Dis. 38: 101-108.

Willette, M., J. Ponder, L. Cruz-Martinez, L. Arent, I. Bueno Padilla, O.N. de Francisco \& P. Redig. 2009. Management of select bacterial and parasitic conditions of raptors. Vet. Clin. North Am. Exot. Anim. Pract. 12: 491-517.

Ziman, M., A. Colagross-Schouten, S. Griffey \& B. Stedman. 2004. Haemoproteus spp. and Leucocytozoon spp. in a captive raptor population. J. Wild. Dis. 40: 137-140. 